\title{
DOUPE LECTURE
}

\section{Torsten O. Nielsen MD, PhD, FRCPC}

Associate Professor

Pathology and Laboratory Medicine

University of British Columbia

\section{Discovery research to clinical trial: A ten year journey}

\begin{abstract}
Clinician-scientists have the training and motivation to translate basic science into tools for improved clinical care, but the road to achieve this is hardly straight forward, particularly for large scale genomic datasets. This year's Joe Doupe Young Investigator award winner, Dr. Torsten Nielsen, details successful examples of new scientific insights, diagnostics and clinical trials that have resulted from microarray-based gene expression profiling of sarcomas: TLE1 as a biomarker for synovial sarcoma, histone deacetylase inhibitor therapy for translocation-associated sarcomas of young adults, and CSF1 pathway inhibitors for tenosynovial giant cell tumors. Results from exciting, emerging next generation sequencing technologies will need to undergo similar validation and preclinical studies before they can be expected to impact patient care.
\end{abstract}

\section{Correspondence to:}

Torsten O. Nielsen, MD, PhD, FRCPC

Anatomical Pathology, JP1502

c/o Rm 1401, JP Pavilion

Vancouver Hospital \& Health Sciences Ctr

855 West 12th Avenue, Vancouver, BC (V5Z 1M9)

Email: torsten@interchange.ubc.ca 
The year 2000 was full of excitement in the clinical research community, arising from the development of new microarray technologies that promised an entirely new and comprehensive view of the molecular biology of human disease. In many ways, the recent application of these next generation sequencing technologies to medical research has generated similar anticipation that major clinical breakthroughs are just around the corner. Clinician-scientists realize, however, that the actual clinical implementation of such basic science and discoverybased research is another matter entirely, requiring years of research and development, most of which are ultimately unsuccessful in changing clinical practice. The path is rarely direct or clear, requiring multiple steps not only in the science itself, but also in obtaining the training, funding, personnel, infrastructure and (what may be most difficult of all for clinicianinvestigators) time to organize and achieve these steps. In this article, I will relate the story of how a discovery research project I started as a resident eventually led to multi-institutional implementation of a new diagnostic test, and to two cancertargeted therapy clinical trials that began accruing patients in autumn 2010.

\section{Clinician-scientist training and research}

I trained in the McGill MD/PhD program, but the key benefits of combined medical and scientific training can also be achieved by many other routes, including separate degrees, research-intensive residencies, clinician-investigator programs, and fellowship training. Clinical training confers a diverse knowledge and perspective on human disease, an understanding of the clinical thinking and decision-making process (including such mantras as first-do-no-harm, focus on diseases that are common and/or dangerous and/or fixable, and "if it doesn't change your management, don't order the test"), and an appreciation of the realities of patient care and clinical implementation of new technologies and ideas. Serious research training drives home the principles of proper experimental design (e.g., a positive result is meaningless without a negative control), imparts credibility as a researcher, develops practical skills in the writing and critical appraisal of papers and grants, provides plenty of experience in dealing with failure, and gives the trainee some extra time to observe mentors and role models before making critical decisions about what specialty to pursue and where to do it.

My inspiration as a child came from Terry Fox; I knew early on that I wanted to become a cancer researcher whose work would actually help people. Although I had not originally considered pathology, I came to realize that the day-to-day work in this specialty often concerns cancer. The pathology profession offers access to vital tissue resources, relative control over my time, and places me squarely at the forefront of translational research because molecular biology advances translate most directly into diagnostics and biomarkers, relative to comparatively long timelines for drug development. For other diseases, different specialty choices might provide a better match between research and clinic. The UBC Anatomical Pathology program I joined had the additional advantage of offering large amounts of elective time for research.

Following the release of "The Chipping Forecast" special issue of Nature Genetics, detailing the impending microarray revolution [1], many researchers thought these new techniques might replace the traditional pathology techniques [2]. I was fortunate enough to do a research elective in England, in a laboratory developing and implementing its own microarray technology. Although this research time was productive [3,4], I quickly realized that experience was more important than equipment when it came to generating reliable results. Pat Brown at Stanford was one of the pioneers of cDNA microarray technology, and, with colleagues, had begun to apply these high throughput techniques to neoplastic diseases, leading to breakthroughs in lymphoma [5] and breast cancer [6], among others. By having credible credentials and by asking the right questions, I was able to transform a brief visit to California into a collaborative research project that quickly led to the world's first large scale expression profiling study of soft tissue tumors [7]. This also exposed me to tissue microarrays [8], a new, complementary technology that opened up huge possibilities for translational studies that were easier to do in Canada than in the USA [9].

Among the key lessons I learned from these experiences during residency was the necessity of having both tissue specimens and linked patient data resources in order to perform effective translational research. Although new and exciting, few molecular tests could actually beat established clinical tools such as microscopic morphology. Time was the single most important resource to have, and I was able to leverage the successful residency research program into a short fellowship period to hone clinical subspecialty skills in a low volume, high interest area (sarcomas), and to write up my first grant applications, which secured an academic position with protected research time.

\section{Starting a translational research program}

The New Investigator funding, which I secured from the Terry Fox Foundation, seemed very appropriate for a sarcoma researcher, and I was most grateful for the chance to see if I could succeed as a clinician-scientist. Sarcomas are uncommon but 
frequently large tumors, diagnostically challenging (encompassing nearly 100 subtypes), and, for the most part, they lack effective systemic treatment options. Nevertheless, sarcomas have a fascinating molecular biology that is highly favourable for translation into new clinical tools for diagnosis and treatment [10]. Our expression profiling studies $[7,11]$ had helped crystallize the concept that nearly half of sarcomas have a welldefined molecular oncogenesis, often driven by specific point mutations or translocations. c-kit tyrosine kinase activating mutations had been shown to drive the biology of gastrointestinal stromal tumors [12], leading to the first effective drug therapy (imatinib) for this sarcoma $[13,14]$. I hoped to work toward similar advances for other sarcomas where such breakthroughs had yet to be made.

Among soft tissue sarcomas with a defined underlying molecular event, synovial sarcoma is the most common. This disease typically occurs in the limbs of young adults, and long term survival rates are disappointing (about 50\%) due to the propensity for early and late metastases that are incurable with conventional chemotherapy [15]. Synovial sarcoma is characterized by a pathognomonic $\mathrm{t}(\mathrm{X} ; 18)(\mathrm{p} 11 ; \mathrm{q} 11)$ event, fusing SS18 (a chromatin remodeling protein associated with the SWI-SNF complex and transcriptional activation) to an $S S X$ gene (which interacts with Polycomb proteins, leading to chromatin condensation and gene silencing) [16]. The net effect on transcription was unknown, nor were any inhibitors of SS18 or SSX available.

In 2003, the research strategy for my new laboratory was to draw on expression profile data to identify key pathways, induced by SS18-SSX, that might be targeted by existing drugs never before tested in this disease. Immediately evident in the profile were genes involved in body segment patterning and mesenchymal differentiation, including retinoid-response genes[7,17,18]. These were of particular interest due to the breakthrough of retinoic acid-based differentiation therapy for promyelocytic leukemia [19], which also bears a fusiontranscription factor translocation (PML-RAR $\alpha$ ). Although chemical and pharmaceutical retinoids were readily available for testing, it took well over a year for me to hire personnel, staff and equip my first lab, secure approvals and appropriate disease models, arrange materials transfer agreements, and generate results ... which all proved negative! My hypothesis was wrong. Neither retinoid agonists nor antagonists had significant effects on synovial sarcoma cell growth or death.

\section{The value of the back-up plan}

Fortunately my training in research and in grantsmanship had taught me at least two important things: each tested hypothesis should have a back up plan in place in case it is wrong, and the research program should encompass multiple aims that are not dependent on each other's success. In leukemia, retinoid resistance can be overcome through the actions of histone deacetylase (HDAC) inhibitors, which, when tested by ourselves and others, appeared highly effective in synovial sarcoma preclinical models [20]. HDAC inhibitors are an emerging class of drugs that reverse epigenetic changes, frequently leading to reactivation of gene expression $[21,22]$.

Concurrent aims to develop diagnostic tools for synovial sarcoma using tissue microarrays were making significant progress $[23,24]$, identifying TLE1 as the most sensitive and specific immunohistochemical marker yet known for synovial sarcoma [22]. This diagnostic test has since been adopted at multiple institutions worldwide [25]. Importantly, TLE1 is known to function as a transcriptional corepressor in key developmental pathways. Thus, we began to view the critical function of the SS18-SSX oncoprotein as abnormal transcriptional repression rather than activation, and sought to identify repressed genes within synovial sarcoma gene expression profiles that might be critical to synovial sarcoma oncogenesis. By combining our primary tumor data with published in vitro model data [26], we were able to identify EGRI (a tumor suppressor gene with a role in muscle differentiation) as a direct target of the SS18-SSX oncoprotein [27]. Chromatin immunoprecipitation experiments demonstrated that treatment with HDAC inhibitors reversed SS18-SSX-mediated Polycomb recruitment and epigenetic gene silencing events, restoring expression of EGR1. EGR1 then goes on to reactivate expression of the critical PTEN tumor suppressor gene, explaining the connection between synovial sarcoma oncogenesis and this well known cancer pathway for the first time [28]. Reactivation of EGRI appears critical to the mechanism of action of HDAC inhibitors in synovial sarcoma, as siRNA knockdown of EGRI abrogates drug-induced apoptosis. Thus, we finally had a drug that inhibits a direct action of the synovial sarcoma oncoprotein.

\section{Translating the basic science into a clinical trial}

The lack of effective systemic therapies for synovial sarcoma, coupled with the completion of phase I and II trials in hematopoetic neoplasms for several HDAC inhibitors, suggested an opportunity to move to human studies without necessarily requiring lengthy animal studies first to be performed. Synovial sarcomas are rare enough that no single institution will accrue enough cases for a reasonable trial design. Indeed, a major problem in sarcoma medical oncology has been the biologically-inappropriate lumping of all soft tissue sarcomas 
TABLE 1. Translocation-associated sarcomas eligible for accrual into NCIC-CTG IND.200

\begin{tabular}{|c|c|c|c|c|c|}
\hline Disease & 5' partner & 3' partner & Peak age & typical site & $\begin{array}{c}\text { response to conventional } \\
\text { chemotherapy }\end{array}$ \\
\hline alveolar rhabdomyosarcoma & $P A X 3$ (or $P A X 7)$ & FKHR (or NCOA1) & $6-9$ & extremity (muscle) & + \\
\hline alveolar soft part sarcoma & $A S P L$ & TFE3 & $15-35$ & extremity (muscle) & - \\
\hline clear cell sarcoma & EWSR1 & ATF1 (or CREB1) & $20-40$ & extremity (tendon) & - \\
\hline $\begin{array}{l}\text { desmoplastic small round cell } \\
\text { tumor }\end{array}$ & EWSR 1 & $W T 1$ & $20-30$ & abdomen & - \\
\hline endometrial stromal sarcoma & $\begin{array}{c}J A Z F 1(\text { or } \\
E P C 1)\end{array}$ & $J J A Z 1 / S U Z 12$ (or PHF1) & $40-50$ & uterus & - \\
\hline Ewing sarcoma & $\begin{array}{c}\text { EWSRI or } \\
\text { FUS) }\end{array}$ & $\begin{array}{c}\text { FLII (or ERG, ETVI, } \\
\text { E1AF, FEVI) }\end{array}$ & $10-20$ & extremity (bone) & ++ \\
\hline $\begin{array}{l}\text { extraskeletal myxoid chondrosar- } \\
\text { coma }\end{array}$ & $\begin{array}{c}\text { EWSR1 } \\
\text { (or } T A F 2 N \text { ) }\end{array}$ & $C H N$ & $20-40$ & extremity (muscle) & - \\
\hline low grade fibromyxoid sarcoma & $F U S$ & $C R E B 3 L 2$ & 35 & extremity (muscle) & - \\
\hline myxoid liposarcoma & $\begin{array}{l}\text { FUS (or } \\
\text { EWSR } 1)\end{array}$ & DDIT3 & $30-50$ & extremity (muscle) & - \\
\hline synovial sarcoma & SS18 & $S S X 1$ (or $S S X 2, S S X 4)$ & $15-35$ & extremity (muscle) & $+/-$ \\
\hline
\end{tabular}

together into studies, done to increase accrual rates and theoretical statistical power [29].

One compromise is to group only the most biologicallysimilar sarcomas together. Synovial sarcomas are part of a group of mesenchymal malignancies characterized by fusion transcription factor translocations (Table 1). All display a phenotype suggestive of blocked mesenchymal differentiation, and most present in the extremities of young adults. An evolving body of evidence suggests a role for abnormal transcriptional repression in these diseases [30,31]; indeed, as a group they appear highly sensitive to the action of HDAC inhibitors (based on results from our lab [32] and others [33,34]).

This work was presented at the NCIC-Clinical Trials Group meetings and caught the attention of the Sarcoma and Investigational New Drug committees. As a result of this attention and in collaboration with medical oncologists Quincy Chu and Elizabeth Eisenhauer, we have been able to initiate IND.200, a phase II study of the HDAC inhibitor SB939 in patients with translocation-associated sarcomas. This study has opened at multiple centres across Canada, with the first patients enrolled in October 2010. In addition to looking for objective response and progression free survival endpoints, correlative science projects embedded in the trial will determine the exact gene translocation present, and test expression of predictive biomarkers using tissue microarrays.

\section{An even faster track to another clinical trial}

The field of sarcomas incorporates many "orphan diseases," and gene expression profiling data almost certainly contains many other leads worthy of investigation and translation [35]. In the case of the tenosynovial giant cell tumor, the combination of DNA and tissue microarray experiments, initiated in collaboration with Drs. West and van de Rijn from Stanford, led to the implication of aberrant macrophage colony-stimulating factor activity (induced by COL6A3-CSF1 translocations) as the underlying biological event [36,37]. This finding immediately implied a potential therapeutic role for CSF1R inhibitors, another emerging drug class under intense development. Indeed, while we were developing preclinical models to test this hypothesis [38], a group in France jumped straight to "off label" treatment of refractory patients using imatinib (on the basis of its cross-inhibition of CSF1R), inducing at least one dramatic complete response [39]. A trial of the closely-related drug nilotinib began in autumn 2010 in the USA (NCT01207492) and in Europe for patients with relapsed or metastatic tenosynovial giant cell tumor, for which we will provide correlative science support.

\section{Perspectives}

By combining clinical knowledge of the problems that need addressing, with research skills on how to employ scientific tools to effectively answer these questions, clinician-scientists have the ability, and indeed the responsibility, to take on leadership roles in translational research. In some cases, where the scientific path is more straight forward, rare diseases may be more worth pursuing than common ones. Regardless, effective translation requires multidisciplinary collaborations including basic scientists, laboratory and diagnostic physicians, surgical and medical specialists, and statisticians. Actually implementing new advances into practice requires prospective studies that 
often need to involve front line physicians, clinical trials groups, industrial collaborators, and health system policy considerations.

Microarray research drove many new discovery advances, and a decade later several have reached the point of clinical implementation in prospective studies. We are currently poised on the edge of a similar revolution, based on next generation sequencing technologies [40]. As costs rapidly decrease, medical scientists are gaining the ability to generate not only quantitative data about expression and copy number (in a digital fashion, superior to hybridization-based microarray methods), but also qualitative data about point mutations and other DNA sequence changes that underlie genetic contributions to disease. Generating vast volumes of data is easier than ever before, and the real trick again will be how to make sense of it all. Bioinformatics techniques play a large part, but in health research the ultimate meaning in the data will lie in improvements to patient care. This translational research will be one of the great opportunities and responsibilities for the new generation of clinician-scientists.

\section{Acknowledgments}

I would like to thank all the researchers who worked in my sarcoma lab from the time we got started until the initiation of IND.200: Jeffrey Chow, Jeff Terry, Suzanne Liu, Joanna Lubieniecka, Neal Poulin, Wanda Kwan, Hongwei Cheng, Jim Dodge, Amanda Jagdis, Helen Gao and Angela Goytain. I would also like to thank the members of the NCICCTG who helped translate this research into a clinical trial, particularly Vivien Bramwell, Quincy Chu and Elizabeth Eisenhauer. The funding agencies that provided initial support for me as a New Investigator included the Michael Smith Foundation for Health Research and the Terry Fox Foundation and the CIHR. Ongoing support for this work has been provided by the Cancer Research Society, Inc. and the Canadian Cancer Society (grant \#018355).

\section{References}

1. Lander ES. Array of hope. Nat Genet. 1999; 21(1 Suppl):3-4.

2. Ladanyi M, Chan WC, Triche TJ, Gerald WL. Expression profiling of human tumors: the end of surgical pathology? J Mol Diagn. 2001; 3(3):92-7.

3. Crnogorac-Jurcevic T, Efthimiou E, Nielsen T, Loader J, Terris B, Stamp G, Baron A, Scarpa A, Lemoine NR. Expression profiling of microdissected pancreatic adenocarcinomas. Oncogene. 2002; 21(29):4587-94.
4. Crnogorac-Jurcevic T, Nielsen TO, Lemoine NR. RT-PCR from laser-capture microdissected samples. Methods Mol Biol. 2002; 193:197-204.

5. Alizadeh AA, Eisen MB, Davis RE, Ma C, Lossos IS, Rosenwald A, Boldrick JC, Sabet H, Tran T, Yu X, Powell JI, Yang L, Marti GE, Moore T, Hudson J, Jr., Lu L, Lewis DB, Tibshirani R, Sherlock G, Chan WC, Greiner TC, Weisenburger DD, Armitage JO, Warnke R, Levy R, Wilson W, Grever MR, Byrd JC, Botstein D, Brown PO, Staudt LM. Distinct types of diffuse large B-cell lymphoma identified by gene expression profiling. Nature. 2000; 403(6769):503-11.

6. Perou CM, Jeffrey SS, van de Rijn M, Rees CA, Eisen MB, Ross DT, Pergamenschikov A, Williams CF, Zhu SX, Lee JC, Lashkari D, Shalon D, Brown PO, Botstein D. Distinctive gene expression patterns in human mammary epithelial cells and breast cancers. Proc Natl Acad Sci U S A. 1999; 96(16):9212-7.

7. Nielsen TO, West RB, Linn SC, Alter O, Knowling MA, O'Connell JX, Zhu S, Fero M, Sherlock G, Pollack JR, Brown PO, Botstein D, van de Rijn M. Molecular characterisation of soft tissue tumours: a gene expression study. Lancet. 2002; 359(9314):1301-7.

8. Kononen J, Bubendorf L, Kallioniemi A, Barlund M, Schraml P, Leighton S, Torhorst J, Mihatsch MJ, Sauter G, Kallioniemi OP. Tissue microarrays for high-throughput molecular profiling of tumor specimens. Nat Med. 1998; 4(7):844-7.

9. Hewitt SM. Tissue microarrays as a tool in the discovery and validation of tumor markers. Methods Mol Biol. 2009; 520:151-61.

10. Borden EC, Baker LH, Bell RS, Bramwell V, Demetri GD, Eisenberg BL, Fletcher CD, Fletcher JA, Ladanyi M, Meltzer P, O'Sullivan B, Parkinson DR, Pisters PW, Saxman S, Singer S, Sundaram M, van Oosterom AT, Verweij J, Waalen J, Weiss SW, Brennan MF. Soft tissue sarcomas of adults: state of the translational science. Clin Cancer Res. 2003; 9(6):1941-56.

11. Wunder JS, Nielsen TO, Maki RG, O'Sullivan B, Alman BA. Opportunities for improving the therapeutic ratio for patients with sarcoma. Lancet Oncol. 2007; 8(6):513-24.

12. Hirota S, Isozaki K, Moriyama Y, Hashimoto K, Nishida T, Ishiguro S, Kawano K, Hanada M, Kurata A, Takeda M, Muhammad Tunio G, Matsuzawa Y, Kanakura Y, Shinomura Y, Kitamura Y. Gain-of-function mutations of c-kit in human gastrointestinal stromal tumors. Science. 1998; 279(5350):577-80.

13. Blanke CD, Demetri GD, von Mehren M, Heinrich MC, Eisenberg B, Fletcher JA, Corless CL, Fletcher CD, Roberts PJ, Heinz D, Wehre E, Nikolova Z, Joensuu H. Long-term results from a randomized phase II trial of standard- versus higher-dose imatinib mesylate for patients with unresectable or metastatic gastrointestinal stromal tumors expressing KIT. J Clin Oncol. 2008; 26(4):620-5.

14. Joensuu H, Roberts PJ, Sarlomo-Rikala M, Andersson LC, Tervahartiala $P$, Tuveson $D$, Silberman $S$, Capdeville R, Dimitrijevic $S$, Druker B, Demetri GD. Effect of the tyrosine kinase inhibitor 
STI571 in a patient with a metastatic gastrointestinal stromal tumor. N Engl J Med. 2001; 344(14):1052-6.

15. Krieg AH, Hefti F, Speth BM, Jundt G, Guillou L, Exner UG, von Hochstetter AR, Cserhati MD, Fuchs B, Mouhsine E, Kaelin A, Klenke FM, Siebenrock KA. Synovial sarcomas usually metastasize after $>5$ years: a multicenter retrospective analysis with minimum follow-up of 10 years for survivors. Ann Oncol.

16. de Bruijn DR, Nap JP, van Kessel AG. The (epi)genetics of human synovial sarcoma. Genes Chromosomes Cancer. 2007; 46(2):107-17.

17. Allander SV, Illei PB, Chen Y, Antonescu CR, Bittner M, Ladanyi M, Meltzer PS. Expression profiling of synovial sarcoma by cDNA microarrays: association of ERBB2, IGFBP2, and ELF3 with epithelial differentiation. Am J Pathol. 2002; 161(5):1587-95.

18. Nagayama S, Katagiri T, Tsunoda T, Hosaka T, Nakashima Y, Araki N, Kusuzaki K, Nakayama T, Tsuboyama T, Nakamura T, Imamura M, Nakamura Y, Toguchida J. Genome-wide analysis of gene expression in synovial sarcomas using a cDNA microarray. Cancer Res. 2002; 62(20):5859-66.

19. Siddikuzzaman, Guruvayoorappan C, Berlin Grace VM. All Trans Retinoic Acid and Cancer. Immunopharmacol Immunotoxicol.

20. Ito T, Ouchida M, Morimoto Y, Yoshida A, Jitsumori Y, Ozaki T, Sonobe H, Inoue H, Shimizu K. Significant growth suppression of synovial sarcomas by the histone deacetylase inhibitor FK228 in vitro and in vivo. Cancer Lett. 2005; 224(2):311-9.

21. Santini V, Gozzini A, Ferrari G. Histone deacetylase inhibitors: molecular and biological activity as a premise to clinical application. Curr Drug Metab. 2007; 8(4):383-93.

22. Yoo CB, Jones PA. Epigenetic therapy of cancer: past, present and future. Nat Rev Drug Discov. 2006; 5(1):37-50.

23. Nielsen TO, Hsu FD, O'Connell JX, Gilks CB, Sorensen PH, Linn S, West RB, Liu CL, Botstein D, Brown PO, van de Rijn $M$. Tissue microarray validation of epidermal growth factor receptor and SALL2 in synovial sarcoma with comparison to tumors of similar histology. Am J Pathol. 2003; 163(4):1449-56.

24. Terry J, Barry TS, Horsman DE, Hsu FD, Gown AM, Huntsman DG, Nielsen TO. Fluorescence in situ hybridization for the detection of $\mathrm{t}(\mathrm{X} ; 18)(\mathrm{p} 11.2 ; \mathrm{q} 11.2)$ in a synovial sarcoma tissue microarray using a breakapart-style probe. Diagn Mol Pathol. 2005; 14(2):77-82.

25. Knosel T, Heretsch S, Altendorf-Hofmann A, Richter P, Katenkamp K, Katenkamp D, Berndt A, Petersen I. TLE1 is a robust diagnostic biomarker for synovial sarcomas and correlates with $\mathrm{t}(\mathrm{X} ; 18)$ : analysis of 319 cases. Eur J Cancer. 46(6):1170-6.

26. de Bruijn DR, Allander SV, van Dijk AH, Willemse MP, Thijssen J, van Groningen JJ, Meltzer PS, van Kessel AG. The synovial-sarcoma-associated SS18-SSX2 fusion protein induces epigenetic gene (de)regulation. Cancer Res. 2006;

66(19):9474-82.
27. Lubieniecka JM, de Bruijn DR, Su L, van Dijk AH, Subramanian S, van de Rijn M, Poulin N, van Kessel AG, Nielsen TO. Histone deacetylase inhibitors reverse SS18-SSX-mediated polycomb silencing of the tumor suppressor early growth response 1 in synovial sarcoma. Cancer Res. 2008; 68(11):4303-10.

28. Su L, Cheng H, Sampaio AV, Nielsen TO, Underhill TM. EGR1 reactivation by histone deacetylase inhibitors promotes synovial sarcoma cell death through the PTEN tumor suppressor. Oncogene. 2010; 29(30):4352-61.

29. Chao J, Chow WA, Somlo G. Novel targeted therapies in the treatment of soft-tissue sarcomas. Expert Rev Anticancer Ther. 10(8):1303-11.

30. Owen LA, Kowalewski AA, Lessnick SL. EWS/FLI mediates transcriptional repression via NKX2.2 during oncogenic transformation in Ewing's sarcoma. PLoS One. 2008; 3(4):e1965.

31. Richter GH, Plehm S, Fasan A, Rossler S, Unland R, BennaniBaiti IM, Hotfilder M, Lowel D, von Luettichau I, Mossbrugger I, Quintanilla-Martinez L, Kovar H, Staege MS, Muller-Tidow C, Burdach S. EZH2 is a mediator of EWS/FLI1 driven tumor growth and metastasis blocking endothelial and neuroectodermal differentiation. Proc Natl Acad Sci U S A. 2009; 106(13):5324-9.

32. Liu S, Cheng H, Kwan W, Lubieniecka JM, Nielsen TO. Histone deacetylase inhibitors induce growth arrest, apoptosis, and differentiation in clear cell sarcoma models. Mol Cancer Ther. 2008; 7(6):1751-61.

33. Hrzenjak A, Kremser ML, Strohmeier B, Moinfar F, Zatloukal $\mathrm{K}$, Denk H. SAHA induces caspase-independent, autophagic cell death of endometrial stromal sarcoma cells by influencing the mTOR pathway. J Pathol. 2008; 216(4):495-504.

34. Sonnemann J, Dreyer L, Hartwig M, Palani CD, Hong le TT, Klier U, Broker B, Volker U, Beck JF. Histone deacetylase inhibitors induce cell death and enhance the apoptosis-inducing activity of TRAIL in Ewing's sarcoma cells. J Cancer Res Clin Oncol. 2007; 133(11):847-58.

35. Nielsen TO, West RB. Translating gene expression into clinical care: sarcomas as a paradigm. J Clin Oncol. 2010; 28(10):1796-805.

36. West RB, Rubin BP, Miller MA, Subramanian S, Kaygusuz G, Montgomery K, Zhu S, Marinelli RJ, De Luca A, Downs-Kelly E, Goldblum JR, Corless CL, Brown PO, Gilks CB, Nielsen TO, Huntsman D, van de Rijn M. A landscape effect in tenosynovial giant-cell tumor from activation of CSF 1 expression by a translocation in a minority of tumor cells. Proc Natl Acad Sci U S A. 2006; 103(3):690-5.

37. Cupp JS, Miller MA, Montgomery KD, Nielsen TO, O'Connell JX, Huntsman D, van de Rijn M, Gilks CB, West RB. Translocation and expression of CSF1 in pigmented villonodular synovitis, tenosynovial giant cell tumor, rheumatoid arthritis and other reactive synovitides. Am J Surg Pathol. 2007; 31(6):970-6. 
38. Cheng H, Clarkson PW, Gao D, Pacheco M, Wang Y, TO. N. Therapeutic Antibodies Targeting CSF1 Impede Macrophage Recruitment in a Xenograft Model of Tenosynovial Giant Cell Tumor. Sarcoma. 2010; 2010:1-7. doi:10.1155/2010/174528.

39. Blay JY, El Sayadi H, Thiesse P, Garret J, Ray-Coquard I. Complete response to imatinib in relapsing pigmented villonodular synovitis/tenosynovial giant cell tumor (PVNS/TGCT). Ann Oncol. 2008; 19(4):821-2.

40. Aparicio SA, Huntsman DG. Does massively parallel DNA resequencing signify the end of histopathology as we know it? J Pathol. 2010; 220(2):307-15. 